J. AMER. SOC. HorT. SCI. 115(3):444-452. 1990.

\title{
Wound Healing in Cucumber Fruit
}

\author{
William M. Walter, Jr. ${ }^{1}$, Betsy Randall-Schadel ${ }^{2}$, and William E. Schadel ${ }^{3}$ \\ U.S. Department of Agriculture, Agricultural Research Service, North Carolina Agricultural \\ Research Service, Department of Food Science, North Carolina State University, Raleigh,
}

NC 27695-7624

Additional index words. lignification, suberization, sclerified parenchyma, wound periderm, Cucumis sativus

\begin{abstract}
Wound healing in cucumber fruit (Cucumis sativus L., cv. Calypso) was studied using histological and degradative techniques. A thick exudate appeared at the wounded surface shortly after wounding. This material retarded water loss and possibly aided in the formation of sclerified parenchyma observed 24 hours after wounding. The sclerified material was positive to a modified Weisner stain, indicating lignification was occurring. Wound periderm (cork) was initiated directly beneath the sclerified parenchyma cells within 48 hours after wounding. The cork layers were positive to Sudan IV stain, indicating suberin was being formed. The rate of phellem development decreased by 6 days after wounding. By day 7, younger phellem cells and sclerified parenchyma cells were stained by Sudan IV. Degradation of the wound tissue by chemical procedures demonstrated that relatively large amounts of lignin and suberin were deposited during healing. Fragments from the lignin degradation Indicated that lignin was composed mainly of gualacyl and p-hydroxyphenyl residues. Suberin was found to contain mainly 1,16-hexadecane and 1,18-osctadecene decarboxylic acids detected as the silylated diol derivatives.
\end{abstract}

Wound healing by plants has significant theoretical and practical impact. Successful postharvest storage of plant organs depends on the ability of the plant material to resist invasion by pathogenic microorganisms. Commercially important plant organs generally are wounded during harvest and handling before storage. The frequency and severity of wounding varies with the "nature of the harvested material, the environmental conditions during harvest, and the implements used for harvest and transporation. Since wounds can serve as avenues for microbial attack and moisture loss, rapid wound healing is required if organ decay and/or desiccation are to be avoided.

Wound responses differ with regard to plant species and organ (El Hadidi, 1969; Rittinger et al., 1987). In many dicotyledons, wounds are closed by deposition of biopolymers in cells adjacent to the wounded area, followed by formation of a wound periderm or cork beneath the sealed area. The deposited material has been shown, in some cases, to be suberin (Cottle and Kolattukudy, 1982) and lignin-like in others (Walter and Schadel, 1983). Suberin is believed to contain an aromatic domain, lignin-like in nature, that is covalently bonded to the cell wall and an aliphatic domain bonded to the aromatic regions (Kolattukudy, 1984). Suberized tissue generally has an affinity for lipid stains such as Sudan IV and, upon reductive depolymerization with $\mathrm{Li} \mathrm{Al} \mathrm{H}$, yields a family of mono- and di-alcohols with carbon chain lengths ranging from $\mathrm{C}_{16}$ through $\mathrm{C}_{30}$. Lignified tissue has little affinity for Sudan IV stain, but is highly reactive with Weisner stain (Walter and Schadel, 1983). Reductive depolymerization yields only small amounts of mpno- and di-alcohols, while alkaline oxidation gives relatively large amounts of p-hydroxybenzaldehyde and vanillin. Alkaline oxidation of suberized tissue gives similar degradation products, Thus, using

Received for publication 2 Feb. 1989. Paper no. 11,985 of the Journal Series of the North Carolina Agricultural Research Service, Raleigh, NC 27695-7643. Mention of a trademark or proprietary product does not constitute a guarantee or warranty of the product by the USDA or North Carolina Agricultural Research Service, nor does it imply approval to the exclusion of other products that may be suitable. The cost of publishing this paper was defrayed in part by the payment of page charges. Under postal regulations. this paper therefore must be hereby marked advertisement solely to indicate this fact.

${ }^{1}$ Research Chemist and Professor.

${ }^{2}$ Current address: Plant Industry Division, North Carolina Dept. of Agriculture, Raleigh.

${ }^{3}$ Current address: Carolina Power and Light Co., Raleigh, N.C. a combination of histochemical stains and depolymerization, the nature of the wound response can be fairly well characterized.

Cucumbers destined for processing uses generally are not stored for long periods of time. However, during periods when the fruit is not available locally, it is transported from distant locations and, as a result, several days may elapse before processing is begun. Wounds inflicted during harvest and shipping could result in serious raw material losses. Cucumber fruit wounded by cutting gave Weisner positive material, indicating that ligoccurring (Behr, 1949). However, a detailed study of the wound healing process 'for cucumber fruit has not been published. This investigation was initiated to study wound healing in cucumber, fruit using a combination of histological and chemical techniques.

\section{Materials and Methods}

\section{Histology}

Cucumber fruit were harvested on three dates from one spring planting. Twenty-one size no. 3 cucumbers $(3.8$ to $5.1 \mathrm{~cm}$ in diameter) were collected on each of the first two dates; 21 fruit of size no. 2 (2.7 to $3.8 \mathrm{~cm}$ in diameter), 21 of size no. 3 , and 21 of size no. $4(>5.1 \mathrm{~cm}$ in diameter, oversized) cucumbers were collected on the third harvest date. Cucumbers were washed, dried, and wounded by removing a 12 - to $19-\mathrm{mm}$-diameter and 2 - to 3-mm-deep patch of tissue with a razor blade. The wounding technique was a reproducible simulation of a moderately severe slice wound. Three wounds were cut on each cucumber from the first harvest date; four wounds were cut per cucumber from the second and third harvest dates. Wounds were cut in a longitudinal row from blossom end to stem end. Wounded cucumbers were placed in a Forma Scientific environmental chamber (model 39412-1; Marietta, Ohio) at $\approx 26 \mathrm{C}$ and $85 \%$ to $90 \%$ RH. Three cucumbers were removed on days 1 through 7 for the first and second harvests, and on days 1 through 7 and day. 10 for the third harvest. Wounds were excised in a block of tissue, fixed in $3 \%$ glutaraldehyde in $0.1 \mathrm{M}$ sodium acetate buffer $(\mathrm{pH} 5.5)$ and stored at $4 \mathrm{C}$. After 5 to 6 days at $4 \mathrm{C}$, wounded tissue was vacuum-infiltrated with fixative at 10 to $15 \mathrm{psi}$ and $21 \mathrm{C}$ for three or four 2 -hr periods. Infiltrated tissue was stored at $4 \mathrm{C}$ for 1 to 2 days, rinsed overnight in $0.1 \mathrm{M}$ sodium acetate buffer ( $\mathrm{pH}$ 5.5), dehydrated in an ethanol-tertiary butyl alcohol series (Johansen, 1940), vacuum-infiltrated, and embedded in Paraplast Plus (Monoject Scientific, St. Louis). Embedded tis- 


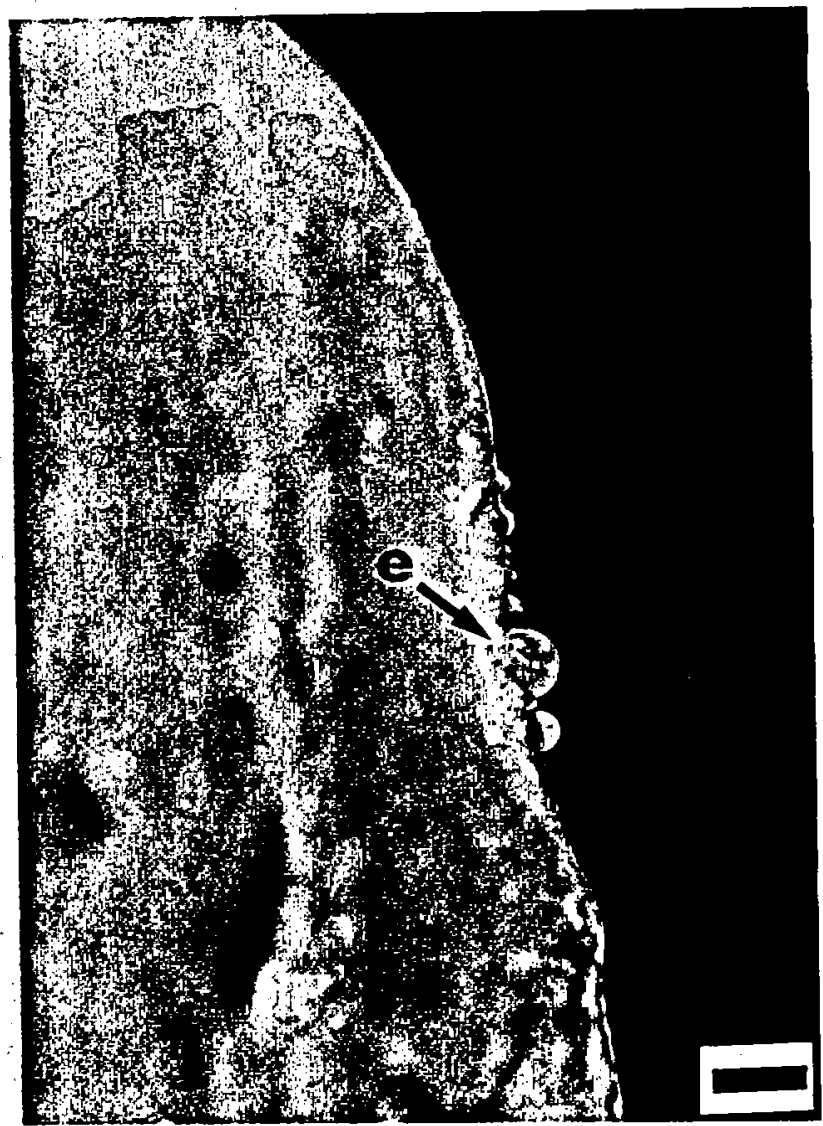

Fig. 1. Side view of exudate in stem end of 'Calypso' cucumber immediately after wounding. $\mathrm{e}=$ Exudate. Bar, $=5 \mathrm{~mm}$.

sue was sectioned at 12 to $14 \mu \mathrm{m}$ on a rotary microtome, mounted using Haupt's adhesive (Johansen, 1940), and air-dried.

Embedded sections were deparaffinized and rehydrated for anatomical and histochemical examination of the wound tissue. Wound tissue anatomy was examined using darkfield microscopy. Stains included were phloroglucinol-HC1 (PG) reagent (Walter and Schadel, 1982) for detecting aldehydes associated with lignin formation in sclerified tissues and Sudan IV (Bradbury, 1973) for detecting suberized and cutinized tissue. Other tests and stains used on deparaffinized sections included Periodic Acid-Schiff (PAS) reaction for insoluble polysaccharides (Bradbury, 1973); orcinol for oleoresinous substances (Johansen, 1940); ruthenium red-methylene blue for differentiating suberin, lignin, sclerenhyma, and parenchyma (Gray, 1954); aniline sulfate-methylene blue for differentiating lignin, sclerenchyma, pectin, and cellulose (Garr, 1965); toluidine blue for cellulose (Feder and O'Brien, 1968) and lignin (O'Brien et al., 1964); and the Maule reaction for lignin (Bradbury, 1973). Catechol was applied directly to fresh wounds and exudates from fresh wounds to detect polyphenol oxidase (Schadel and Walter, 1981). PG reagent and orcinol were also applied directly to fresh wound tissue. Fresh tissue was hand-sectioned and examined for starch with a weak iodine solution and heat (Johansen, 1940). Fresh wounds were excised and fixed in ferrous sulfate (Johansen, 1940) to detect tannins.

\section{Color tests}

Wound tissue from each sample day was excised by slipping a razor blade directly under the wound and then placing the excised wound tissue directly into PG reagent for $10 \mathrm{~min}$. Tissue

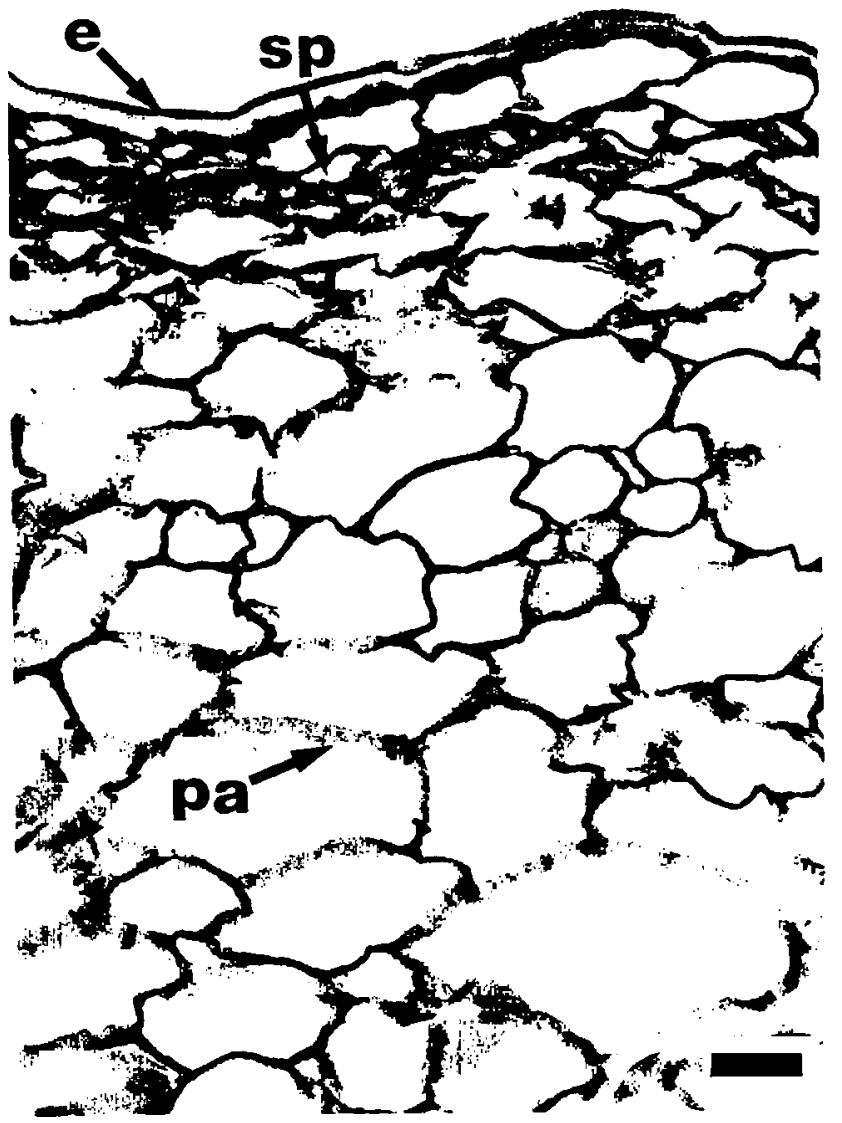

Fig. 2. Cross-section of wounded 'Calypso' cucumber hypodermis and outer mesocarp after 1 day at $26 \mathrm{C}$ and $85 \%$ to $90 \%$ RH. e = Exudate, $\mathrm{sp}=$ sclerified parenchyma (positive reaction with phloroglucinol-HC1 reagent), $\mathrm{pa}=$ normal parenchyma. $\mathrm{Bar}=50 \mu \mathrm{m}$.

was removed from the reagent, blotted dry, and macroscopic color reactions were scored visually using a scale of $1=$ no color change, 2 = pale pink, $2.5=$ patchy pink, $3=$ medium to deep pink, and $4=$ purple.

\section{Data analysis}

Analysis of variance using the General Linear Models procedure (SAS Institute, 1985) served to identify statistically significant trends. Where appropriate, mean separation was done by the Waller-Duncan $\mathrm{K}$ ratio $t$ test and the $t$ statistic (SAS Institute, 1985).

\section{Biopolymer analysis}

Tissue purification. Fruit from harvests 1 and 2 were wounded and placed in the environmental chambers described above. After 7 days, the fruit were removed and wound tissue excised. In addition, samples of periderm and mesocarp were also removed. The tissue samples were purified as previously described for sweetpotato tissue (Walter and Schadel, 1983). After air-drying, the purified tissue was ground to $\leq 60 \mathrm{mesh}$, vacuum-dried (50C), and stored in a desiccator at room temperature.

Alkaline cupric oxide oxidation. Powdered samples of periderm, wound, and mesocarp tissue $(60 \mathrm{mg})$ were mixed with $1.7 \mathrm{~g} \mathrm{CuSO}_{4} \cdot 5 \mathrm{H}_{2} \mathrm{O}$ and $10 \mathrm{ml}$ of $3 \mathrm{~N} \mathrm{NaOH}$ and heated at $180 \mathrm{C}$ for $3 \mathrm{hr}$ in a sealed tube. The residue was neutralized, extracted with ether, and the resulting alcohols derivitized with acetic anhydride prior to gas-liquid chromatographic (GLC) 
Table 1. Comparison by day of cell layer scores combined from harvests I and II of sclerified parenchyma, phellem, and sclerenchyma cells on wounded 'Calypso' cucumbers.

\begin{tabular}{|c|c|c|c|c|c|c|c|}
\hline \multirow[b]{3}{*}{ Day } & \multicolumn{6}{|c|}{ Mean scores } & \multirow[b]{3}{*}{ Sclerenchymay } \\
\hline & \multicolumn{3}{|c|}{ Sclerified parenchyma ${ }^{x}$} & \multicolumn{3}{|c|}{ Phellem² } & \\
\hline & Sudan IV & Phloroglucinol & Morphological & Sudan IV & Phloroglucinol & Morphological & \\
\hline $\begin{array}{c}1 \\
2 \\
3 \\
4 \\
5 \\
6 \\
7 \\
\text { Trend }\end{array}$ & $\begin{array}{l}1.0 \\
2.3 \\
3.0 \\
3.0 \\
3.0 \\
3.0 \\
3.0 \\
40\end{array}$ & $\begin{array}{l}2.0 \\
2.2 \\
2.4 \\
2.9 \\
3.0 \\
3.0 \\
3.0 \\
0\end{array}$ & $\begin{array}{l}2.0 \\
2.3 \\
3.0 \\
3.0 \\
3.0 \\
3.0 \\
3.0\end{array}$ & $\begin{array}{l}1.0 \\
1.0 \\
2.2 \\
2.3 \\
3.2 \\
4.7 \\
4.8 \\
\end{array}$ & $\begin{array}{l}1.0 \\
1.0 \\
1.2 \\
2.0 \\
2.8 \\
4.4 \\
4.6 \\
\end{array}$ & $\begin{array}{l}1.0 \\
2.0 \\
3.5 \\
3.5 \\
4.5 \\
5.7 \\
5.7 \\
* *\end{array}$ & $\begin{array}{l}1.0 \\
1.0 \\
1.0 \\
1.8 \\
2.2 \\
3.5 \\
3.2 \\
+10\end{array}$ \\
\hline $\mathbf{S E}^{\mathbf{X}}$ & 0.03 & 0.04 & 0.09 & 0.08 & 0.06 & 0.03 & 0.10 \\
\hline
\end{tabular}

${ }_{\mathrm{Z}}^{\mathrm{Z}}$ core values assigned to given cell layers: $1=0$ cell layer; $2=0$ to $1 ; 2.5=0$ to $2 ; 3=1$ to $2 ; 3.5=1$ to $3 ; 4=$ 2 to $3 ; 4.5=2$ to $4 ; 5=3$ to $4 ; 5.5=3$ to $5 ; 6=4$ to $5 ; 7=5$ to 6 .

${ }^{\mathrm{y}}$ Score values assigned to relative abundance of sclerenchyma cells: $1=$ no sclerenchyma cells; $2=\mathrm{a}$ few scattered (one to two) layers present, but lightly; 3 = several scattered layers when present (or one to two layers for a large area, moderate); 4 = several layers (two to four) covering a large area (heavy).

${ }^{x} \mathrm{SE} \geq$ standard error of the mean.

$* *$ Significant at $\mathrm{P} \leq 0.001$.

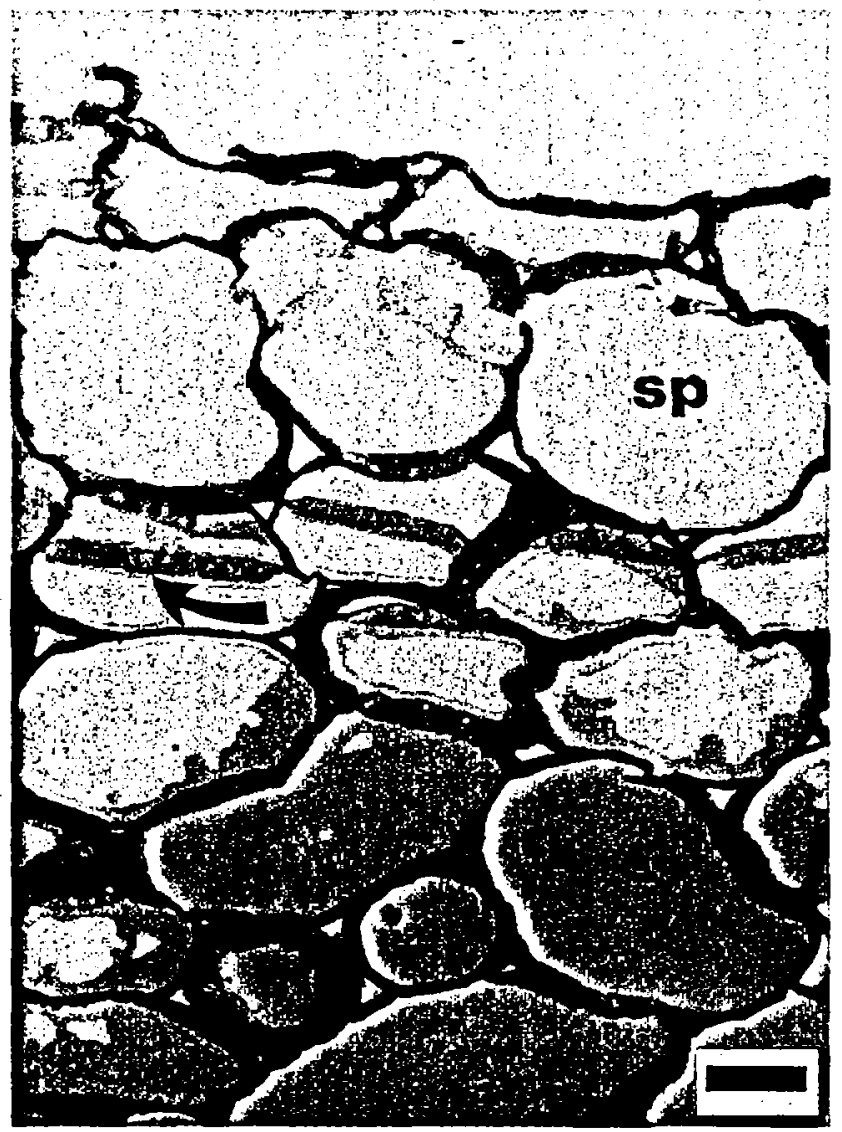

Fig. 3. Cross-section of wounded 'Calypso' cucumber outer mesocarp after 2 days at $26 \mathrm{C}$ and $85 \%$ to $90 \%$ RH. Note wound periderm initiation (curved arrow). Exudate was disrupted during sectioning. $\mathrm{sp}=$ Sclerified parenchyma. $\mathrm{Bar}=50 \mu \mathrm{m}$.

analysis (Walter and Schadel, 1983). The internal standard, 7hydroxy coumarin, was added before ether extraction.

Reductive depolymerization. Samples of purified periderm, wound, and mesocarp tissues $(60 \mathrm{mg})$ were refluxed overnight with $\mathrm{Li} \mathrm{Al} \mathrm{H}_{4}$ in tetrahydrofuran. The sample work-up was as described previously (Walter and Schadel, 1983), except that

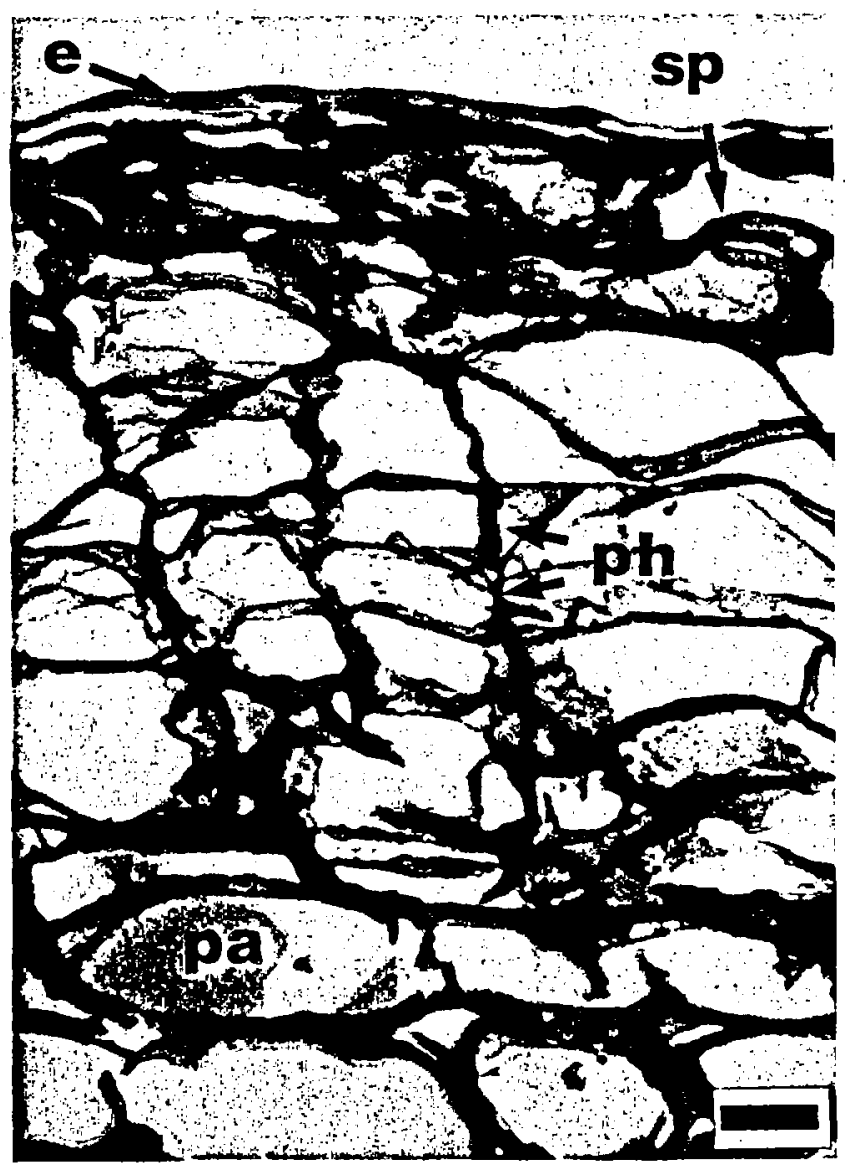

Fig. 4. Cross-section of wounded 'Calypso' cucumber hypoderrnis and outer mesocarp after 10 days at 26C and $85 \%$ to $90 \%$ RH with well-formed wound periderm. Note sclerenchyma absent. e $=$ Exudate, $\mathrm{sp}=$ sclerified parenchyma, $\mathrm{pa}=$ normal parenchyma, $\mathrm{ph}$ $=$ phellem (positive reaction with Sudan IV). Bar $=50 \mu \mathrm{m}$.

the internal standard used was 1,12-dihydroxydodecane. After isolation of the dihydroxy fragments by thin-layer chromatography, they were transformed into trimethylsilyl ethers before mass spectrometery and quantitation by GLC. 


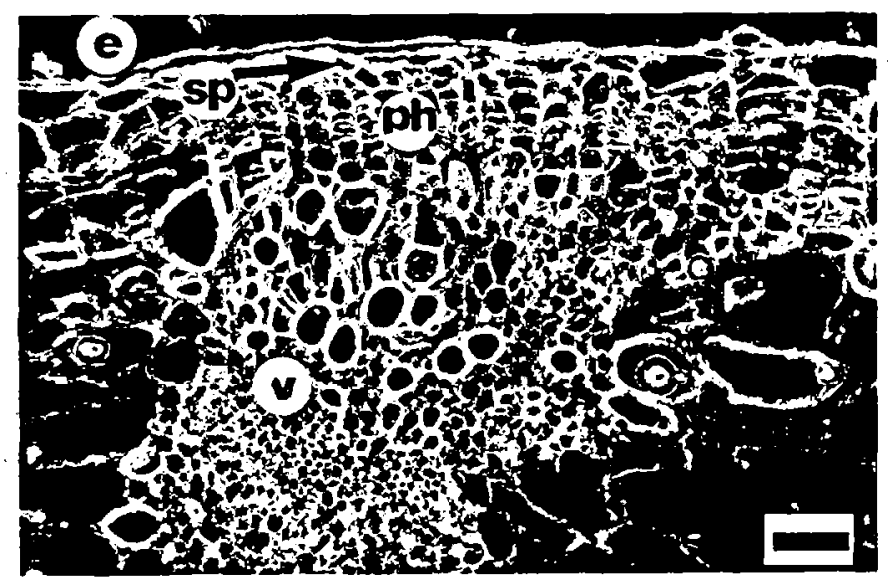

Fig. 5. Cross-section of wounded 'Calypso' cucumber epidermis and hypodermis after 6 days at $26 \mathrm{C}$ and $85 \%$ to $90 \%$ RH with vascular tissue and well-formed periderm above vascular tissue. e = Exudate; $=$ sclerifed parenchyma, $\mathrm{ph}=$ phellem cells (reacted positively with Sudan IV), v = vascular bundle. Bar $=100 \mu \mathrm{m}$.

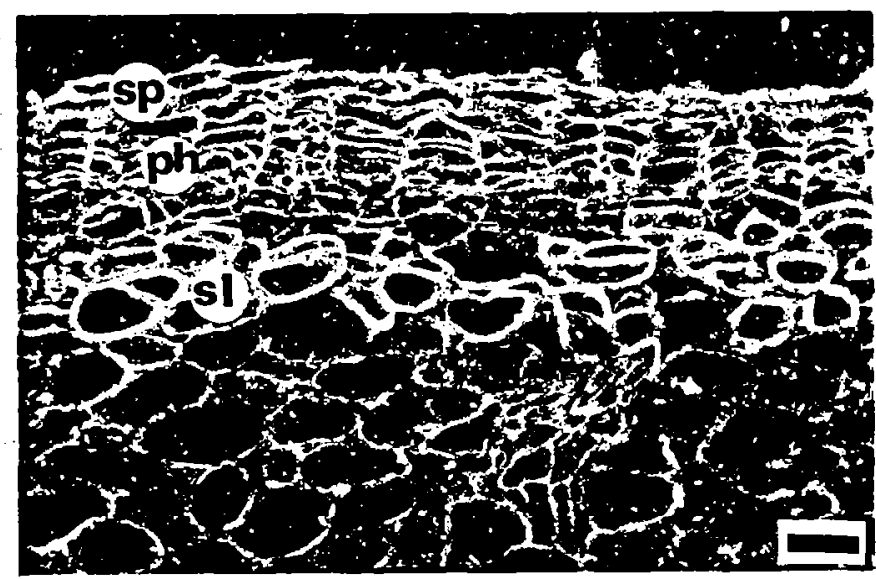

Fig. 6. Cross-section of wounded 'Calypso' cucumber epidermis and hypodermis after 7 days at $26 \mathrm{C}$ and $85 \%$ to $90 \% \mathrm{RH}$. No vascular tissue in section. Exudate was disrupted during sectioning. Sclerenchyma cells are prominent beneath wound. $\mathrm{sp}=$ Sclerified parenchyma cells (reacted positively with phloroglucinol-HC1 reagent); $\mathrm{ph}=$ phellem cells (reacted positively with Sudan IV); sl = sclerenchyma cells. Bar $=100 \mu \mathrm{m}$.

Gas-liquid chromatography. Acetylated products of the alkaline cupric oxide oxidation of lignin have been identified previously and were shown to be present in sweetpotato periderm and wound tissue (Walter and Schadel, 1983). Authentic samples of the expected breakdown products were obtained commercially (Aldrich, Milwaukee, Wis.), acetylated, and used as standards for quantitation. The GLC system used was a Packard model 803 containing a $3 \times 3 \mathrm{~mm}$ i.d. glass column packed with $3 \%$ OV101 on Supelcoport $80 / 100$ mesh. The column temperature was programmed to increase $5 \mathrm{C} / \mathrm{min}$ beginning at $140 \mathrm{C}$ and ending at $225 \mathrm{C}$, with a final hold of $8 \mathrm{~min}$. Individual components were quantitated by determination of each response factor relative to the internal standard 7-hydroxycoumarin. A Hewlett-Packard model 3390A integrator was used to measure peak areas.

Compounds released from cucumber tissue by $\mathrm{Li} \mathrm{Al} \mathrm{H}_{4}$ reduction were quantitated by the same GLC system as above, except that the separation was conducted isothermally at $250 \mathrm{C}$ and the internal standard used for calculation of the response

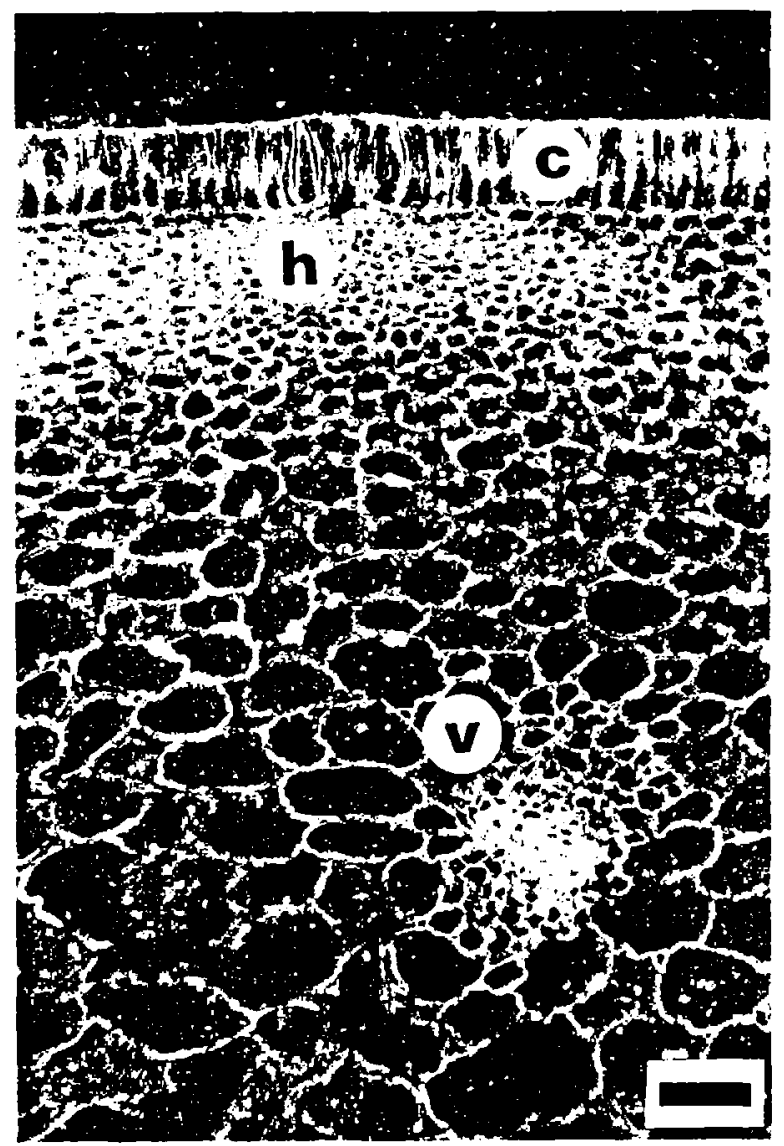

Fig. 7. Cross-section of unwounded 'Calypso' cucumber epidermis and hypodermis. $\mathrm{c}=$ Cuticle, $\mathrm{h}=$ hypodermis, $\mathrm{v}=$ vascular bundle. $\mathrm{Bar}=100 \mu \mathrm{m}$.

factors was 1,12-dihydroxydodecane. Identification was done with a Hewlett-Packard model 5985 GC/MS. The column used was a $30 \times 0.32 \mathrm{~mm}$ i.d. capillary column coated with $\mathrm{DB}$ 1701. The initial column temperature was 200C (1-min hold), then programmed to $275 \mathrm{C}$ at $5 \mathrm{C} / \mathrm{min}$ (20-min hold). The carrier gas $(\mathrm{He})$ inlet pressure was $0.77 \mathrm{~kg} \cdot \mathrm{cm}^{-2}$. Mass spectra were obtained at $70 \mathrm{eV}$ ionizing voltage.

\section{Results and Discussion}

\section{Histology}

The initial response of the cucumber to wounding was production of a clear, sticky exudate (Fig. 1). The exudate covered the entire wound surface, forming thick droplets in places and eventually drying to form a presumably protective layer over the wound. Behr (1949) observed this exudate and found a negative relationship between depth of wound and intensity of exudate production, suggesting the exudate was not initiated in the pulp. He did note a relationship between maturity of the fruit and intensity of exudate production: the younger the fruit, the greater the intensity of exudate production. He attributed this relationship to the higher fluid contents, etc. of young cells.

No desiccation was observed for uninjured parenchyma cells at the wound surface; the exudate appears to provide a moisture barrier and to facilitate rapid cork initiation. Wounded sweetpotatoes that do not produce a copious exudate exhibit varying degrees of desiccation of the uninjured parenchyma cells at the wound surface. The degree of desiccation varies with relative 


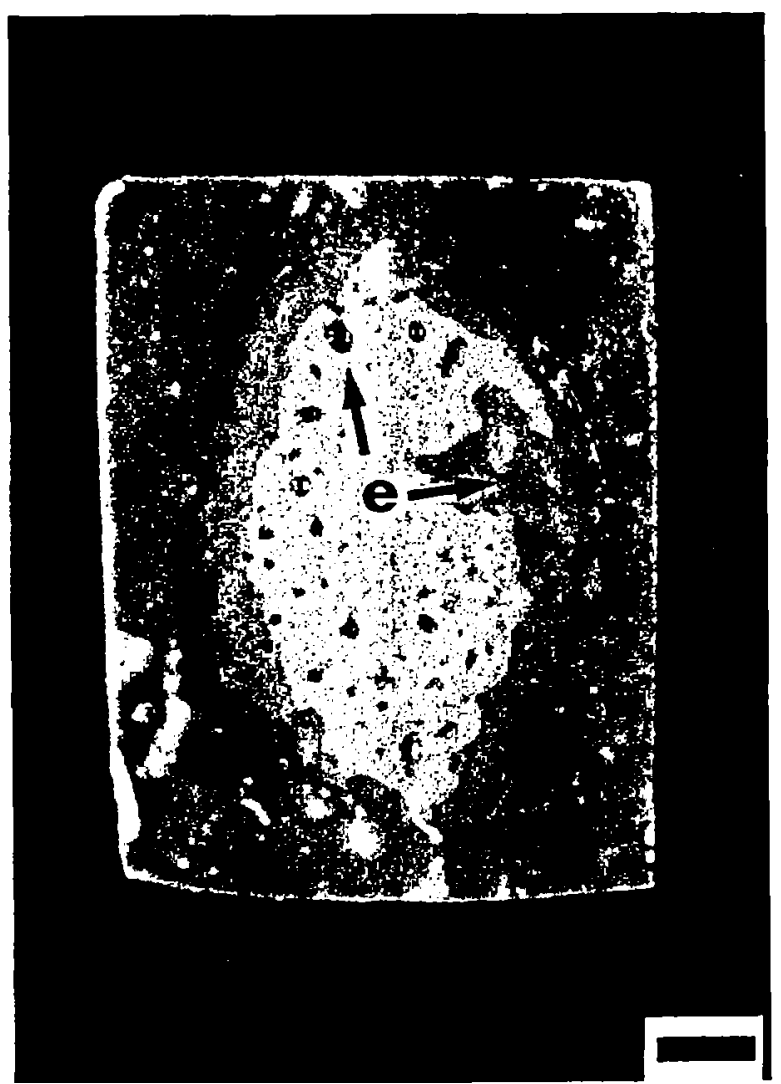

Fig. 8. Excised 'Calypso' cucumber wounds after fixation in 3\% glutaraldehyde in $0.15 \mathrm{M} \mathrm{NaOAc}$ buffer, $\mathrm{pH}$ 5.5. Note dark coloration of exudate droplets and clear coloration of exudate between droplets. Exudate droplets were red, which appeared dark in this photograph. e $=$ Exudate. Bar $=3 \mathrm{~mm}$.

humidity and temperature, and desiccation was associated with thickening of the cell walls (lignification or suberization) be- neath the desiccated area. This thickening continues to subtending cells until the wound cork is initiated (Walter and Schadel, 1982). Poor wound cork formation has been observed in sweetpotatoes where no desiccation occurred (Weimer, 1921). This pattern leads to speculation as to whether the exudate on cucumbers provides protection by preventing desiccation or by providing a barrier that is represented by desiccated cell layers in the sweetpotato.

\section{Cork formation}

Daily development of cork formation in wounded cucumbers held at $26 \mathrm{C}$ and $85 \%$ to $90 \% \mathrm{RH}$ was observed microscopically (Table 1). After 1 day, zero to one layer of parenchyma cells directly beneath the exudate reacted positively with the phloroglucinol-HC1 reagent (PG), indicating that aldehydes associated with lignin were being deposited (Fig. 2). Up to two parenchyma cell layers reacted positively with PG by day 3 . The cells in these two layers (henceforth referred to as sclerified parenchyma) gave no morphological indication of desiccation. Rarely were more than two cell layers of the parenchyma thus sclerified. The positive PG results concur with those observed by Behr (1949) on the walls of dead cells and of several healthy cells beneath wounds on cucumber petioles. El-Din-Fouad (1956) did not observe staining by PG of healthy cells adjacent to the wound area in any Cladsoporum cucumerinum -susceptible cucumber tissue examined (cotyledons, leaves, petioles, and stems), although dead cells beneath the wounds did not react positively with PG.

Cork was initiated directly beneath sclerified parenchyma. Sudan IV, a test for fatty acids associated with suberin, yielded positive results as early as day 3 for the phellem. Staining usually intensified, and the number of cell layers increased over time. By day 6, the Sudan IV was staining the last initiated phellem cells. Phellem was often initiated by day 2 (Fig. 3). When it was initiated by day 2 , the phellem was patchy and only one to two cell layers thick. By day 5, the phellem thickened to three. to four cell layers. The phellem occasionally thickened to as many as eight cells by day 10, although the four to

Table 2. Response of cucumber tissue 10 histological stains.

\begin{tabular}{|c|c|c|c|c|c|c|c|c|}
\hline Tissue & Sudan IV & Phloroglucinol & Orcinol & $\begin{array}{l}\text { Ruthenium red- } \\
\text { methylene blue }\end{array}$ & $\begin{array}{c}\text { Maule } \\
\text { reaction }\end{array}$ & $\begin{array}{l}\text { Aniline sulfate- } \\
\text { methylene blue }\end{array}$ & $\begin{array}{c}\text { Toluidine } \\
\text { blue }\end{array}$ & $\begin{array}{c}\text { Periodic } \\
\text { acid-Schiff }\end{array}$ \\
\hline Epidermis & + (red) & - & - & $\begin{array}{l}+ \text { (walls pink } \\
\text { to red) }\end{array}$ & - & + (dark blue) & + (deep & + (blue) \\
\hline $\begin{array}{l}\text { Normal } \\
\text { parenchyma }\end{array}$ & - & - & - & $\begin{array}{l}+ \text { (dark smoky } \\
\text { purple) }\end{array}$ & - & + (light blue) & + (purple) & $+\underset{\text { purple) }}{\text { (reddish }}$ \\
\hline $\begin{array}{l}\text { Sclerified } \\
\text { parenchyma }\end{array}$ & $+($ red) & $+($ red) & + (red) & $\begin{array}{l}+ \text { (pink to } \\
\text { red) }\end{array}$ & - & + (datk blue) & + (purple) & $+\begin{array}{c}\text { (reddish } \\
\text { purple) }\end{array}$ \\
\hline $\begin{array}{l}\text { Wound } \\
\text { phellem }\end{array}$ & + (red) & $\pm \underset{\text { red })}{\text { (pinkish }}$ & & $\begin{array}{l}\text { (only two cell } \\
\text { layers +; } \\
\text { green) }\end{array}$ & - & + (turquoise) & + (purple) & $\begin{array}{c}+ \text { (reddish } \\
\text { purple) }\end{array}$ \\
\hline $\begin{array}{l}\text { Sclerenchyma } \\
\text { Xylem } \\
\text { elements }\end{array}$ & $\bar{t}$ & + (purplish) & & $\begin{array}{l}+ \text { (pink) } \\
\pm \text { (greenish } \\
\text { hue) }\end{array}$ & - & $\begin{array}{l}\text { (0 in section) } \\
+ \text { (soft green } \\
\text { to bluish } \\
\text { green) }\end{array}$ & $\begin{array}{c}+ \text { (blue) } \\
+ \text { (bluish } \\
\text { green) }\end{array}$ & $\begin{array}{l}+ \text { (blue) } \\
+ \text { (purple) }\end{array}$ \\
\hline Exudate & & - & - & - & - & - & + (blue) & $+\underset{\text { brown })}{\text { (pale }}$ \\
\hline Cuticle & + (red) & - & - & - & - & $+\underset{\text { blue })}{\text { (pale/light }}$ & & \\
\hline $\begin{array}{l}\text { Stain } \\
\text { specificity }\end{array}$ & $\begin{array}{l}\text { Fatty acids } \\
\text { (suberin } \\
\text { and cutin) }\end{array}$ & $\begin{array}{l}\text { Aromatic } \\
\text { aldehydes } \\
\text { (lignin } \\
\text { and gums) }\end{array}$ & $\begin{array}{r}\text { Oleoresinous } \\
\text { substances }\end{array}$ & $\begin{array}{l}\text { To differentiate } \\
\text { suberin, lignin, } \\
\text { sclerenchyma, and } \\
\text { parenchyma }\end{array}$ & Lignin & $\begin{array}{l}\text { To differentiate } \\
\text { lignin, } \\
\text { sclerenchyma, } \\
\text { pectin, and } \\
\text { cellulose }\end{array}$ & Cellulose & $\begin{array}{l}\text { Insoluble } \\
\text { polysaccharides }\end{array}$ \\
\hline
\end{tabular}


Table 3. Comparison by day of cell layer scores from harvests I and II of sclerified parenchyma, phellem, and sclerenchyma cells on wounded 'Calypso' cucumbers.

\begin{tabular}{|c|c|c|c|c|c|c|c|c|}
\hline \multirow[b]{3}{*}{ Harvest } & \multirow[b]{3}{*}{ Day } & \multicolumn{7}{|c|}{ Mean scores } \\
\hline & & \multicolumn{3}{|c|}{ Sclerified parenchyma ${ }^{2}$} & \multicolumn{3}{|c|}{ Phellem $^{2}$} & \multirow[b]{2}{*}{ Sclerenchymay } \\
\hline & & Sudan IV & Phloroglucinol & Morphological & Sudan IV & Phloroglucinol & Morphological & \\
\hline \multirow[t]{9}{*}{$I$} & 1 & 1.0 & 2.0 & 2.0 & 1.0 & 1.0 & 1.0 & 1.0 \\
\hline & 2 & 2.3 & 2.3 & 2.3 & 1.0 & 1.0 & 2.0 & 1.0 \\
\hline & 3 & 3.0 & 2.5 & 3.0 & 2.0 & 1.3 & 3.3 & 1.0 \\
\hline & 4 & 3.0 & 2.8 & 3.0 & 2.0 & 2.0 & 3.3 & 2.0 \\
\hline & 5 & 3.0 & 3.1 & 3.0 & 3.0 & 2.7 & 5.0 & 2.7 \\
\hline & 6 & 3.0 & 3.0 & 3.0 & 5.0 & 4.0 & 5.7 & 3.7 \\
\hline & 7 & 3.0 & 3.0 & 3.0 & 5.0 & 4.7 & 6.0 & 3.0 \\
\hline & Trend & $\because$ & $\because$ & $\because$ & $* *$ & $* *$ & $* *$ & $* *$ \\
\hline & $\mathrm{SE}^{\mathbf{x}}$ & 0.06 & 0.07 & 0.06 & 0.14 & 0.10 & 0.14 & 0.16 \\
\hline \multirow[t]{7}{*}{ II } & $\because 1$ & 1.0 & 2.0 & 2.0 & 1.0 & 1.0 & 1.0 & 1.0 \\
\hline & 2 & 2.3 & 2.0 & 2.3 & 1.0 & 1.0 & 2.0 & 1.0 \\
\hline & 3 & 3.0 & 2.3 & 3.0 & 2.3 & 1.0 & 3.7 & 1.0 \\
\hline & 4 & 3.0 & 3.0 & 3.0 & 2.7 & 2.0 & 3.7 & 1.7 \\
\hline & 5 & 3.0 & 2.8 & 3.0 & 3.3 & 2.8 & 4.0 & 1.7 \\
\hline & 6 & 3.0 & 3.0 & 3.0 & 4.3 & 4.8 & 5.7 & 3.3 \\
\hline & 7 & 3.0 & 3.0 & 3.0 & 4.7 & 4.5 & 5.3 & 3.3 \\
\hline Trend & & $* *$ & $* *$ & $* *$ & $* *$ & $* *$ & $* *$ & $* *$ \\
\hline $\mathrm{SE}^{\mathrm{x}}$ & . & 0.06 & 0.07 & 0.06 & 0.13 & 0.10 & 0.14 & 0.15 \\
\hline
\end{tabular}

${ }^{\mathrm{z}}$ Score values assigned to given cell layer: $1=0$ cell layer; $2=0$ to $1 ; 2.5=0$ to $2 ; 3=1$ to $2 ; 3.5=1$ to $3 ; 4=2$ to $3 ; 4.5$ $=2$ to $4 ; 5=3$ to $4 ; 5.5=3$ to $5 ; 6=4$ to $5 ; 7=5$ to 6 .

${ }^{\mathrm{y}}$ Score values assigned to relative abundance of sclerenchyma cells: $1=$ no sclerenchyma cells; $2=$ a few scattered (one to two) layers present, but lightly; 3 = several scattered layers when present (or one IO two layers for a large area, moderate); $4=$ several layers (two to four) covering a large area (heavy).

${ }^{\mathrm{x}} \mathrm{SE}=$ standard error of the mean.

** Significant at $P \leq 0.001$.

Table 4. Mean scores for macroscopic color reactions of phloroglucinol-HC1 reagent on excised 'Calypso' cucumber wounds from harvests II and III.

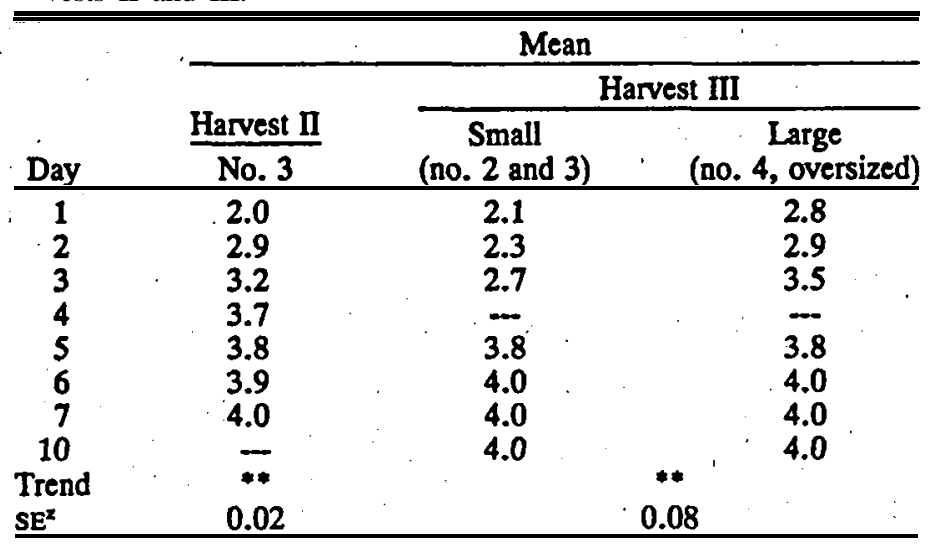

${ }^{\mathrm{z}} \mathrm{SE}=$ standard error of the mean.

** Significant at $P \leq 0.01$.

six layers of phellem were a more typical thickness (Fig. 4). The patchy distribution of the phellem could still be observed as late as day 10 . Phellem was most rapidly and heavily produced next to the vascular tissue (Fig. 5). One to two layers of phelloderm were usually produced by day 7 (Fig. 6).

Sclerenchyma cells were occasionally observed beneath the phelloderm beginning with day 4 . These cells were usually patchy, but, in some samples, extended over much of the wounded area (Fig. 6). The morphology of the sclerenchyma cells resembles the hypodermal cells at the base of the emergence or wart described by Barber (1909). These cells are sclerenchymatized, thickened, and pitted. Barber (1909) suggests the thickening of these cells may serve to prevent evaporation or entrance of a pathogen after the emergence is removed. Esau (1977) refers to scattered sclerids present beneath the hypoderm in cucurbits in general, but no reference was made specifically to sclerids in Cucumis sativus. The sclerenchyma cells noted here reacted positively with PG, but did not stain with Sudan IV. Tissue adjacent to the wound appeared unaffected (Fig. 7).

Thickened portions of the exudate on the wound surface slowly turned bright red when tissue was placed in glutaraldehyde fixative. The thickened exudate appeared in Fig. 8 as dark-colored droplets. The thin, smooth areas of the exudate remained opaque. Only two histochemical tests or stains reacted positively with the exudate on deparaffinized sections and fresh wound tissuethese were toluidine blue (Table 2) and PAS counterstained with toluidine blue. Other areas, however, had positive results with several stains or tests. Orcinol yielded results similar to PG, again indicating the presence of aldehydes associated with lignin in the outermost cell layers of the wound. The Maule reaction, specific for syringyl groups (Vance et al., 1980), yielded negative results on these outermost cell layers. PG (a modified Wiesner test) reacts predominantly with substituted cinnamaldehyde groups and only weakly with syringyl groups (Vance et al., 1980).

General trends in significant differences for combined data from harvests I and II existed among the number of layers of sclerified, phellem, and sclerenchyma cells over time, regardless if determination was based on morphological features or stains (Table 1). The groupings were generally distinct. When the values were analyzed separately for harvests I and II (Table 3 ), groupings were very similar for all characteristics except two. These were morphological determinations of sclerenchyma cells and phellem, which varied slightly. 
Table 5. Comparison on days 7 and 10 of cell color scores and microscopic color scores between different-sized, wounded 'Calypso' cucumbers.

\begin{tabular}{|c|c|c|c|c|c|c|c|c|c|}
\hline \multirow{2}{*}{$\begin{array}{c}\text { Cucumber } \\
\text { size }\end{array}$} & \multirow[b]{2}{*}{ Day } & \multicolumn{3}{|c|}{ Sclerified parenchyma cells } & \multicolumn{3}{|c|}{ Phellem } & \multirow[b]{2}{*}{ Sclerenchyma } & \multirow[b]{2}{*}{ Wound } \\
\hline & & Sudan IV & Phloroglucinol & Morphological & Sudan IV & Phloroglucinol & Morphological & & \\
\hline Small & $\begin{array}{r}7 \\
10\end{array}$ & $\begin{array}{l}3.0 \\
3.0\end{array}$ & $\begin{array}{l}3.0 \\
3.0\end{array}$ & $\begin{array}{l}3.0 \\
3.0\end{array}$ & $\begin{array}{l}5.0 \\
7.0\end{array}$ & $\begin{array}{l}4.3 \\
6.3\end{array}$ & $\begin{array}{l}6.0 \\
7.6\end{array}$ & $\begin{array}{l}2.0 \\
3.3\end{array}$ & $\begin{array}{l}4.0 \\
4.0\end{array}$ \\
\hline $\begin{array}{l}\text { Significance } \\
\text { Large }\end{array}$ & $\begin{array}{r}7 \\
10\end{array}$ & $\begin{array}{l}\text { NS } \\
3.0 \\
3.0\end{array}$ & $\begin{array}{l}\text { NS } \\
3.3 \\
3.3\end{array}$ & $\begin{array}{l}\text { NS } \\
3.0 \\
3.0\end{array}$ & $\begin{array}{l}6.0 \\
6.5\end{array}$ & $\begin{array}{l}4.8 \\
5.0\end{array}$ & $\begin{array}{l}6.5 \\
7.3\end{array}$ & $\begin{array}{l}\text { NS } \\
3.3 \\
2.3\end{array}$ & $\begin{array}{l}\text { NS } \\
4.0 \\
4.0\end{array}$ \\
\hline Significance & & NS & NS & NS & NS & NS & NS & NS & NS \\
\hline
\end{tabular}

${ }^{\text {NS, }}$ Not significant or significant at $P \leq 0.05$, respectively, using $t$ statistic.

Table 6. Comparison by harvest for day 7 of all layer scores ${ }^{\mathrm{z}}$ of sclerified parenchyma, phellem, and sclerenchyma cells on wounded 'Calypso' cucumbers.

\begin{tabular}{|c|c|c|c|c|c|c|c|}
\hline \multirow[b]{2}{*}{ Harvesty } & \multicolumn{3}{|c|}{ Sclerified parenchyma } & \multicolumn{3}{|c|}{ Phellem ${ }^{x}$} & \multirow[b]{2}{*}{ Sclerenchymax } \\
\hline & Sudan IV & Phloroglucinol & Morphological & Sudan IV & Phloroglucinol & Morphological & \\
\hline $\begin{array}{l}\text { II } \\
\text { III S } \\
\text { III L }\end{array}$ & $\begin{array}{l}\mathbf{3 . 0} \\
\mathbf{3 . 0} \\
\mathbf{3 . 0} \\
\mathbf{3 . 0}\end{array}$ & $\begin{array}{l}3.0 \\
3.0 \\
3.0 \\
3.3\end{array}$ & $\begin{array}{l}3.0 \\
3.0 \\
3.0 \\
3.0\end{array}$ & $\begin{array}{l}5.0 \mathrm{~A} \\
4.7 \mathrm{~A} \\
5.0 \mathrm{AB} \\
6.0 \mathrm{~B}\end{array}$ & $\begin{array}{l}4.7 \\
4.5 \\
4.3 \\
4.8\end{array}$ & $\begin{array}{l}6.0 \\
5.3 \\
6.0 \\
6.5\end{array}$ & $\begin{array}{l}3.0 \\
3.3 \\
2.0 \\
3.3\end{array}$ \\
\hline MSD & NS & NS & NS & 1.2 & NS & NS & NS \\
\hline
\end{tabular}

${ }^{\mathrm{z}}$ Means separated by Waller-Duncan multiple range test. Within a column, means with the same letter are not significantly different $(P \leq 0.05)$.

${ }^{\mathrm{y}} \mathrm{S}=$ small; $\mathrm{L}=$ large.

${ }^{\mathrm{x}}$ See Table 1 for explanation of score values.

Table 7. Components from cupric oxide oxidation of cucumber, purified wound tissue, periderm, and mesocarp.

\begin{tabular}{llcc}
\hline \hline & \multicolumn{3}{c}{ Quantity (mg.g ${ }^{-1}$ of dry tissue) } \\
\cline { 2 - 4 } Component & \multicolumn{1}{c}{ Woundz } & Periderm $^{2}$ & Mesocarpy \\
\hline$p$-Hydroxybenzaldehyde (HB) & $13.2( \pm 0.4)$ & $2.70( \pm 0.04)$ & ND $^{x}$ \\
$p$-Hydroxyacetophenone (HA) & $2.78( \pm 0.25)$ & $1.21( \pm 0.21)$ & ND \\
Vanillin (VA) & $21.6( \pm 1.3)$ & $2.51( \pm 0.14)$ & 0.77 \\
Acetovanillone (AV) & $7.35( \pm 0.55)$ & $0.60( \pm 0.03)$ & ND \\
Syringaldehyde (SA) & $0.22( \pm 0.05)$ & ND & ND \\
\hline
\end{tabular}

${ }^{\mathrm{z}}$ Tissue from two harvests. Each value is mean of duplicate analyses $( \pm \mathrm{SD})$.

${ }^{\mathrm{y}}$ Tissue from one harvest. Each value is mean of duplicate analyses.

${ }^{\mathrm{x}} \mathrm{ND}=$ not detectable.

Table 8. Components released by $\mathrm{Li} \mathrm{Al} \mathrm{H}_{4}$ reduction of purified cucumber wound, skin, and mesocarp tissue.

\begin{tabular}{lccc}
\hline \hline & \multicolumn{3}{c}{ Quantity $\left(\mathrm{mg} \cdot \mathrm{g}^{-1}\right.$ of dry tissue) } \\
\cline { 2 - 4 } Compound & Wound & Periderm $^{2}$ & Mesocarp \\
\hline 1,16 -Hexadecane diol & $18.13( \pm 0.10)$ & $11.42( \pm 2.38)$ & 0.50 \\
1,18 -Octadecene diol & $29.88( \pm 0.76)$ & $10.01( \pm 1.86)$ & 0.46 \\
\hline
\end{tabular}

${ }_{\mathrm{z}}^{\mathrm{z}}$ Tissue from two harvests. Each value is mean of duplicate analyses $( \pm \mathrm{SD})$.

${ }^{\mathrm{y}}$ Tissue from one harvest. Each value is mean of duplicate analyses.

${ }^{\mathrm{x}}$ Identity established from mass spectrum.

\section{Color tests}

Wound color test scores for harvest II increased rapidly up to day 4, with smaller increases after that (Table 4). This result is similar to the relationship seen microscopically in harvests I and II, with morphological distinctions between days 1, and 2, and no differences among days 3-7 (Table 1). Although the morphological distinctions had disappeared by day 3 , the microscopic PG reactions remained distinct until day 4 , supporting a direct correlation between the number of layers of sclerified parenchyma reacting to $\mathrm{PG}$ with the macroscopic color intensity of PG, as was demonstrated in wounded sweetpotato (Walter and Schadel, 1982).

\section{Cucumber size}

Slight differences occurred in the PG macroscopic color test between large and small cucumbers for days 1, 2, and 3, but, by day 5 , test scores were not significantly different (Table 4). No differences occurred between days or cucumber sizes in number of sclerified parenchyma or sclerenchyma cell layers. Distinct differences did occur, however, between days 7 and 10 for small cucumbers in the phellem, whether determination was made on morphological features or staining reactions (Table 5). Phellem values for large cucumbers on days 7 and 10 were not significantly different. Phellem values were also higher for small cucumbers than for large cucumbers for day 10, and the reverse was true for day 7 . These differences, although pot significantly different when viewed with the macroscopic color tests (Table 4), suggest a trend of slower formation of a sclerified parenchyma cell barrier in small cucumbers, but that small cucumbers can catch up and possibly surpass the larger cucumbers in phellum development.

Scattered clusters of sclerenchyma cells were present in most fruit examined. Two small fruit lacked sclerenchyma cells at day 7 , but the other small fruit at day 7 had four or more layers of sclerenchyma cells present. These layers were usually not continuous across the entire wound. 
When all three harvests were compared for day 7 values (Table 6), no significant differences were found among sclerified parenchyma or sclerenchyma cell layer values, or among PG and morphological determinations of phellem values. The only significantly different values observed were between the Sudan IV-staining phellem cell layers for harvest I and for large fruit from harvest III. Although different rates may occur in the early stages of wound cork formation, by day 7 , in similar environmental conditions, fruit from all harvests and of all sizes were at a similar stage of development.

\section{Biopolymer analysis}

Two chemical approaches were taken in the analysis of the biopolymers from wound, periderm, and mesocarp tissue. Alkaline cupric oxide oxidation is a commonly used degradation method to determine the composition of lignified tissue (Vance et al., 1980; Hammerschmidt, 1985). Reductive depolymerization with $\mathrm{Li} \mathrm{Al} \mathrm{H}_{4}$ has been used to study the aliphatic regions of suberin and cutin (Kolattukudy and Agrawal, 1974; Kolattukudy, 1984). Histochemical studies described in the previous section indicated that lignification was initiated within $24 \mathrm{hr}$ of wounding, and suberization was observed $48 \mathrm{hr}$ after wounding. Since would tissue for analysis was collected 7 days after wounding, it was expected that significant amounts of lignin and suberin biopolymer constituents would be found. Degradation of lignified wound tissue by alkaline cupric oxides resulted in the formation of vanillin (VA) and p-hydroxybenzaldehyde (HB) as the major components, with smaller amounts of syringaldehyde (SA),p-hydroxyacetophenone (HA), and acetovanillone (AV). HB and $\mathrm{HA}$ are derived from p-hydroxyphenyl residues, VA and AV from guaiacyl residues, and SA from syringyl residues. We found that for cucumber wound tissue, VA was the most abundant oxidation product, followed by $\mathrm{HB}$, AV, and HA. SA was present in very small amounts (Table 7). Oxidation products from cucumber periderm lignins were much less abundant than from wound lignins, and their relative distributions were different. Cucumber mesocarp tissue contained almost no lignin. These data also indicated that the lignin in wound and periderm tissues are comprised mainly of p-hydroxyphenyl and guaiacyl residues, but in different ratios. The small amount of SA present in wound tissue is consistent with the negative Maule reaction (Table 2). Asada and Matsumoto (1972) found similar amounts of $\mathrm{HB}$ and VA in wounded radish root inoculated with downy mildew. Walter and Schadel (1983) found that, in sweetpotato roots, VA and HB levels were 5.01 and $1.99 \mathrm{mg} \cdot \mathrm{g}^{-1}$ of wound tissue, respectively, and that periderm and wound tissue were similar in composition. Hammerschmidt (1985) reported that, for two white potato cultivars, HA was greater than VA in wound tissue, while the reverse was true for normal periderm. Absolute amounts of the oxidation products were of the same magnitude as reported for sweetpotato (Walter and Schadel, 1983).

Reductive depolymerization of cucumber tissue gave two major products. These were identified by their mass spectra as 1,16-hexadecanediolsilyl ether and 1,18-octadecenediolsilyl ether. The hexadecane compound had a barely discernible molecular ion at 402 and fragment ions at $\mathrm{m} / \mathrm{e} 387\left(\mathrm{M}^{+}-\mathrm{CH}_{3}\right), \mathrm{m} / \mathrm{e} 371$ $\left(\mathrm{M}^{+}-\mathrm{CH}_{3}-\mathrm{CH}_{4}\right)$, and $\mathrm{m} / \mathrm{e} 312\left[\mathrm{M}^{+}-\mathrm{HO} \mathrm{Si}\left(\mathrm{CH}_{3}\right)\right]$ (Walton and Kolattukudy, 1972). The $\mathrm{C}_{18}$ enediol had a mass spectrum, identical to that reported for sweetpotato wound tissue (Walter and Schadel, 1983). Hydrolysis products recovered from the three types of tissue declined in the order of wound, periderm, and mesocarp (Table 8). The $\mathrm{C}_{18}$ diol made up $62 \%$ of the total hydrolysate in wound tissue, as compared to approximately equal amounts of $\mathrm{C}_{16}$ and $\mathrm{C}_{18}$ diols from the periderm and mesocarp. These findings differ from the study on sweetpotato, which showed that the $\mathrm{C}_{18}$ diol was the major hydrolysis product and that more than seven times as much of this diol was released from the skin as from the wound tissue.

The wound healing process in cucumber is similar to that reported for other plant organs in that the cucumber is protected after wounding from dehydration and to some extent from infection by deposition of biopolymers, such as lignin and suberin. However, in cucumber, a viscous exudate that was released within minutes of wounding effectively sealed the wound and prevented moisture loss so that no visible cellular desiccation occurred. In sweetpotato (Walter and Schadel, 1983), and carrot and potato (Rittinger et al., 1987), several layers of desiccated cells were observed above the healed wound. Within 1 day of wounding cucumbers, PG-positive sclerified parenchyma cells were observed. By the 2nd day, these cells were also positive to Sudan IV, indicating that lignification occurred first, followed immediately by suberization. Usually, this phase of wound healing was completed after two layers of cells beneath the wound had been sclerified. This pattern contrasts with that in sweetpotatoes in which three or more layers of sclerified cells were formed (Walter and Schadel, 1983). Additionally, for sweetpotato wounds, both histological and degradative studies showed that lignin was the predominant biopolymer of sclerified cells. In cucumber, meristematic wound phellem, which was initiated 3 days after wounding, was positive to both PG and Sudan IV, indicating that both lignin and suberin were being deposited. Phellem formation was usually complete within 10 days and consisted of four to six cell layers. In view of the effect of temperature and humidity on wound healing rates, it is improper to compare the results of cucumber with other plants unless similar conditions were used. Chemical analysis of the wound tissue showed that fairly large amounts of lignin and suberin were deposited during the healing process. Both suberized and lignified plant tissues are resistant to attack by fungi and bacteria (Lauritzen, 1935; Brown et al., 1978) and should provide an effective barrier to pathogen invasion.

\section{Literature Cited}

Asada, Y. and I. Matsumoto. 1972. The nature of lignin obtained from downy mildew-infested Japanese radish root. Phytopathol. Z. 73:208214.

Barber, K.G. 1909. Comparative histology of fruits and seeds of certain species of Cucurbitaceae. Bot. Gaz. 47:263-310.

Behr, L. 1949. Histologische Untersuchungen an Kratzekranken Gurken (Cucumis sativus L.) unter besonderer Berücksichtigung des Kraukheitsverlaufes der Kratze (Cladosporium cucumerin Ell. et Arth.) an Früchten. Phytopathol. Z. 15:92-123.

Bradbury, S. 1973. Peacock's elementary microtechnique. 4th cd. Edward Arnold, London.

Brown, G.E., M.A. Ismail, and C.R. Barmore. 1978. Lignification of injuries to citrus fruit and susceptibility to green mold. Proc. Fla. State Hort. Soc. 91:124-126.

Cottle, W. and P.E. Kolattukudy. 1982. Biosynthesis deposition and partial characterization of potato suberin phenolics. Plant Physiol. 69:393-399.

El-Din-Fouad, M.K. 1956. Studies on genetic and on chemically induced resistance of cucumber tissues to Cladosporium cucumerinum (Ell. et Arth.). Mededelingen Van De Landbouwhogeschool te Wageningen/Nederland 56:1-51.

El Hadidi, M.N. 1969. Observations on the wound healing process in some flowering plants. Mikroscopic 25:54-69.

Esau, K. 1977. Anatomy of seed plants. 2nd ed. Wiley, New York. 
Feder, N. and T.S. O’Brien. 1968. Plant microtechnique; some principles and new methods. Amer. J. Bot. 55:123-142.

Garr, E. 1965. The rationale use of dyes in biology and general staining methods. Williams \& Wilkins, Baltimore.

Gray, P. 1954. The microtomist's formulary and guide. Blakiston, New York.

Hammerschmidt, R. 1985. Determination of natural and wound-induced potato tuber suberin phenolic acid derivitization and cupric oxide oxidation. Potato Res. 28:123-127.

Johansen, D.A. 1940. Plant microtechnique. McGraw-Hill, New York.

Kolattukudy, P.E. 1984. Biochemistry and function of cutin and suberin. Can. J. Bot. 62:2918-2933.

Kolattukudy, P.E. and V.P. Agrawal. 1974. Structure and composition of aliphatic components of potato tuber skin (suberin). Lipids 9:682-691.

Lauritzen, J.I. 1935. Factors affecting infection and decay of sweet potatoes by certain storage rot fungi. J. Agr. Res. 50:285-329.

O'Brien, T.P., N. Fedder, and M.E. McCully. 1964. Polychromatic staining of plant cell walls by toluidine blue O. Protoplasma 59:368-373.

Rittinger, P.A., A.R. Biggs, and D.R. Pierson. 1987. Histochemistry of lignin and suberin deposition in boundary layers formed after wounding in various plant species and organs. Can. J. Bot. 65:1886-1892.
SAS Institute, Inc. 1985. SAS user's guide: Statistics. Cary, N.C. Schadel, W.E. and W.M. Walter, Jr. 1981. Localization of phenols and polyphenol oxidase in 'Jewel' sweet potatoes (Ipomoea batatas 'Jewel'). Can. J. Bot. 59:1961-1967.

Vance, C.P., T.K. Kirk, and R.T. Sherwood. 1980. Lignification as a mechanism of disease resistance. Annu. Rev. Phytopathol. 18:259288.

Walter, W.M., Jr., and W.E. Schadel. 1982. A rapid method for evaluating curing progress in sweet potatoes. J. Amer. Soc. Hort. Sci. 107:1129-1133.

Walter, W.M., Jr., and W.E. Schadel. 1983. Structure and composition of normal skin and wound tissue from cured sweet potatoes. J. Amer. Soc. Hort. Sci. 108:909-914.

Walton, T.J. and P.E. Kolattukudy. 1972. Determination of the structures of cutin monomers by a novel depolymerization procedure and combined gas chromatography and mass spectrometry. Biochemistry 11:1885-1896.

Weimer, J.L. 1921. Wound cork formation in the sweet potato. J. Agr. Res. 21:637-647.

J. AMER. SOC. Hort. SCI. 115(3):452-454. 1990.

\title{
Chemical Changes in Okra Stored in Air and Controlled Atmosphere
}

\author{
Lawford Baxter ${ }^{1}$ and Luther Waters, Jr. ${ }^{2}$ \\ Department of Horticultural Science and Landscape Architecture, University of Minnesota, \\ St. Paul, MN 55108
}

Additional index words. Abelmoschus esculentus, sugars, organic acids, amino acid, protein, ascorbic acid

\begin{abstract}
Okra (Abelmoschus esculentus L. Moench) pods stored In a controlled atmosphere (CA) of $5 \% \mathrm{O}_{2}$ and $10 \% \mathrm{CO}_{2}$ at $11 \pm 1 \mathrm{C}$ and in air at the same temperature (RA) were compared to determine the effects of the two storage environments on changes in sugars, organic acids, proteins and amino acids, and ascorbic acid contents within the tissue. Pods were sampled at 3-day intervals for 12 days. CA-stored pods generally had greater retention of sugars, soluble proteins, and amino acids than RA-stored pods. Citric, malic, and ascorbic acids contents of CA pods also declined more slowly than those of RA pods.
\end{abstract}

Okra is well-adapted to hot, humid conditions and is a popular vegetable in most tropical countries. Okra not only serves as a thickening agent for soups and stews, but is an important source of nutrients in the diet $(8,9)$. Fresh okra pods have a short postharvest life, being prone to physical and physiological changes that reduce quality (18).

Postharvest treatments such as hydrocooling (6), chemical sprays (11), and modified atmospheres (MA) (1) have been used to extend the postharvest life and maintain the quality of fresh okra. Modified or controlled atmosphere (CA) in conjunction with low temperatures is particularly attractive, since this storage method is generally considered effective in reducing the respiration rates of fresh vegetables and in maintaining quality while leaving no harmful residues. The effects of MA or CA storage on physical and physiological changes in fresh commodities are variable and there are even conflicting reports on the effects of CA storage on a given commodity in some cases

Received for publication 27 June 1988. Paper no. 16,060 of the Scientific Journal Series, Univ. of Minnesota Agricultural Experiment Station. The cost of publishing this paper was defrayed in part by the payment of page charges. Under postal regulations, this paper therefore must be hereby marked advertisement solely to indicate this fact.

${ }_{2}^{1}$ Graduate student.

${ }^{2}$ Associate Professor.
(20). Little work (1) has been done to determine the response of okra fruits to CA storage. The objective of this work was to determine CA effects on changes in the levels of certain chemical compounds in okra.

\section{Materials and Methods}

'Clemson Spineless' okra was grown on the St. Paul campus of the Univ. of Minnesota using standard commercial practice. Pods were harvested 6 days after anthesis, trimmed, immediately forced-air cooled to $\approx 11 \mathrm{C}$ and placed in a $69 \times 37 \times$ $37 \mathrm{~cm}(\mathrm{~L} \times \mathrm{W} \times \mathrm{H})$ plexiglass chamber that then was sealed. A CA consisting of $5 \% \mathrm{O}_{2}, 10 \% \mathrm{CO}_{2}$, and $85 \% \mathrm{~N}_{2}$ (12), prepared by mixing commercially bottled gas from high-pressure cylinders, was passed through an ethylene scrubber into the chamber. A system of flow meters, solenoid valves, and timers controlled the flow of the gas mixture into the chamber and provided for one complete change of the atmosphere about every $16 \mathrm{hr}$. Temperature and relative humidity were maintained at $11 \pm 1 \mathrm{C}$ and $90 \%$ to $95 \%$, respectively. Control pods were stored at the same temperature and relative humidity in air (RA). Air flow rate in the control chamber was the same as that of the CA chamber. Each test consisted of a single treatment and control chamber with three tests per year for 2 years.

Pods were removed from storage at 3-day intervals for 12 days, freeze-dried, and ground to a fine powder in a cyclone 